\section{Friedman's First Law fails: oil prices do not predict freedom}

Steve Townsend

$\mathrm{O}$ ne issue that has received much attention as a factor in conflict is the presence of natural resources in less-developed countries, oil in particular, and what is called the resource curse. Research is emerging that casts doubt on the resource curse and the way in which oil wealth is supposed to impede democratization. ${ }^{1}$ To be useful, the term oil wealth needs to be separated into its components such as oil reserves, production levels, prices, revenues, profits, royalties, and ownership. This articles focuses on one of these components, price, and how it may affect the level of freedom in countries where oil revenues make up a large share of gross domestic product (GDP). In particular, it will examine the First Law of Petropolitics, a rather extreme extension of the resource curse, put forward by the influential New York Times columnist, Thomas L. Friedman. This first appeared in Foreign Policy in 2006. ${ }^{2}$ The "law" claims that high oil prices cause a decline in the levels of freedom. It contends that freedom flourishes in less-developed countries as soon as oil prices fall.

This article investigates Friedman's claims for the four countries for which he provides data as well as other countries where he claims the law applies. In some cases his data is incomplete and when more complete data is used his claim is refuted. In some cases his data is inappropriate such as when he uses oil prices in current dollars rather than have them converted to constant dollar values. In one important case, Iran, he misinterprets the data to support his thesis but it is clear that, for this example, the correlation is positive, not negative as Friedman's law would require.

It is important to bring these shortcomings to light. Friedman's idea is gaining increasing currency and acceptance among political commentators and even academics. Friedman continues to promote the idea in his New York Times articles, and in television and radio interviews. It has been discussed on several weblogs and has received credence among bloggers on the Private Sector Development Blog maintained by the World Bank. The Economist also concurs with the idea and even accepts that it is a law. ${ }^{3}$

So far, there is not a lot of mention of Friedman's First Law in peer-reviewed journals but it is beginning to appear and has already been used in an article in International Political Science Review to support a new analysis of governance issues. It has also been cited twice in journal articles proposing changes in energy policy and has been reprinted as a reading in a respected text on international relations. ${ }^{4}$ Given the influence Friedman's claims are having, it is important that they be examined and appraised.

\section{What Friedman claims}

According to Friedman's First Law of Petropolitics, "the price of oil and the pace of freedom always move in opposite directions in oil-rich petrolist states." He defines petrolist states as those that depend on oil production for most of their exports or gross domestic product and that also have weak state institutions or outright authoritarian governments. He claims that as the average price of oil increases, freedom of speech, free elections, and the rule of law will decline in these states as will the independence of political parties and the judiciary. When the price of oil decreases, these states will be forced to become more responsive to internal and international criticism and reverse the deterioration. ${ }^{5}$

Much of Friedman's Foreign Policy article consists of anecdotes; these will not be discussed here. The main quantitative thrust of the article is provided in data for four countries: Venezuela, Nigeria, Russia, and Iran. Friedman does no more than present graphs to establish his correlations. In this article, pairwise correlations and probability values are calculated for the strength, direction, and statistical significance of each correlation (employing Pearson's $r$ ).

How good are Friedman's correlations?

Venezuela

For Venezuela, Friedman graphed Freedom House scores and nominal oil prices for the period 1986 to $2005 .{ }^{6}$ Using nominal oil prices rather than inflation-adjusted ones, especially when using data stretching over 20 years, is inappropriate. Friedman offers no explanation for doing so. (Emails to Friedman and to the editor of Foreign Policy on this and other issues have not had a reply.) As to the measure of freedom, Friedman uses the simple average of two Freedom House scores, for political rights and for civil liberties.?

Examining Friedman's 1986-2005 data in Figure 1, a negative correlation between oil prices and freedom levels does appear to exist. The correlation coefficient, $r$, equals -0.60 , a reasonably strong negative correlation, and it shows a strong statistical significance as well ( $p=0.004)$. Of course, a negative value of $r$ is what would be expected when variables are moving in opposite directions.

But Freedom House data are available for Venezuela as from 1972 and inflationadjusted oil prices go even further back in time. The oil prices used here are British Petroleum's mean world crude oil prices in constant 2006 U.S. dollars per barrel. ${ }^{8}$ When these numbers are plotted in Figure 1 as well, it is readily apparent that Friedman's claim falls apart. First, using the inflation-adjusted oil prices, the 


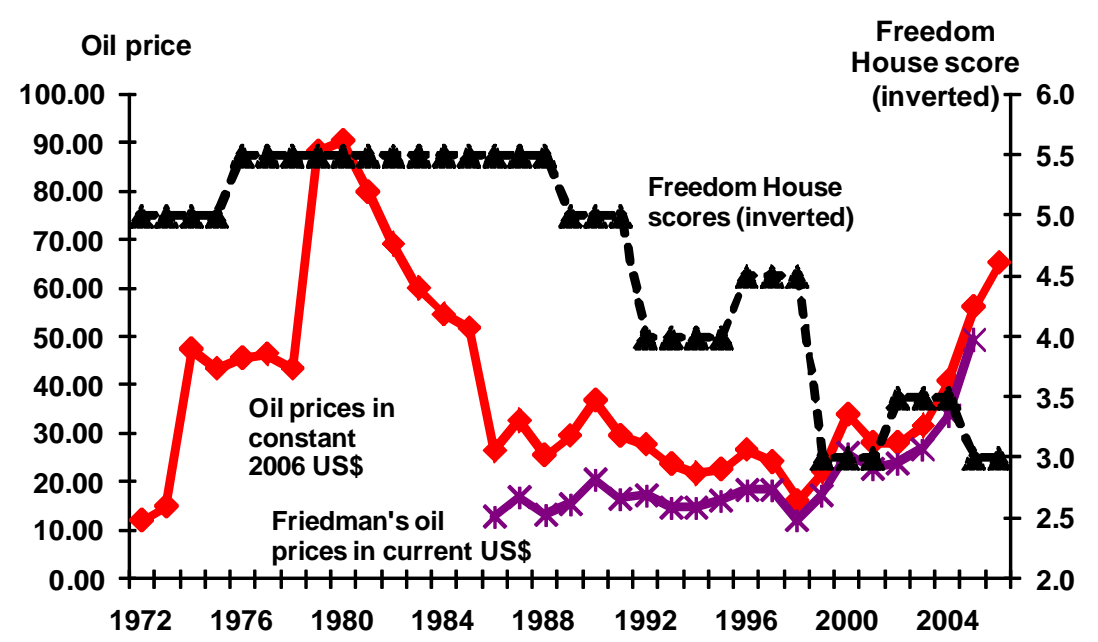

Figure 1: Venezuela, 1972-2006: oil prices and Freedom House scores (inverted).

correlation for Friedman's 1986 to 2005 time period is no longer statistically significant $(r=-0.26, p=0.27)$ and, second, when the time period is extended to 1972 to 2006, the correlation becomes a statistically significant positive one $(r=+0.32 ; p$ $=0.06$ ). Friedman's law is turned on its head.

Table 1: Venezuela,

1972-2006: correlations for oil price in 2006 U.S. dollars and Freedom House scores

$\begin{array}{lcl}\begin{array}{l}\text { Lags } \\ \text { (years) }\end{array} & \begin{array}{c}\text { Pearson's } \\ r\end{array} & \begin{array}{l}p \text { - } \\ \text { value }\end{array} \\ 1 & & \\ 2 & +0.45 & 0.007 \\ 3 & +0.55 & 0.001 \\ 4 & +0.57 & 0.001 \\ & +0.57 & 0.001\end{array}$

A change in oil prices is unlikely to affect a country's level of freedom instantly. Friedman does not discuss the likelihood that the effects of any price changes will be delayed, but obviously this should be considered. Table 1 presents the correlation (and probability) values when the dependent variable (freedom) is lagged by between one to four years. All show reasonably strong positive correlations and with high statistical significance, again turning Friedman's law on its head.

\section{Nigeria}

The graph Friedman presents for Nigeria — the two dashed lines in Figure 2 - also appear to strongly supports his case. The measure of legal structure and property rights and the measure of oil prices certainly seems to move in opposite directions.

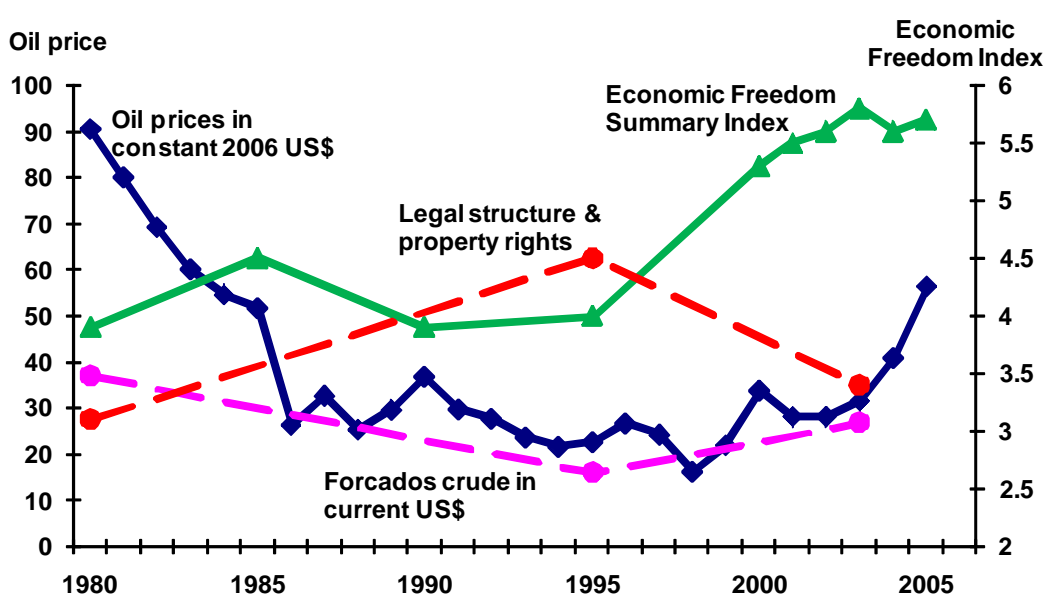

Figure 2: Nigeria, 1980-2005, oil prices and economic freedom.

But while $r=-0.98$, statistical significance is low at $p=0.12$, so a correlation is not certain. This is to be expected when using only three data pairs, as Friedman does. Also, once more there are problems with the data he employed. First, it is puzzling why Friedman provides data only for 1980, 1995, and 2003 when the sources he used had data for the intervening years available. Second, as for Venezuela, he should have converted nominal prices into real prices. And third, we should have examined the effect of inflation-adjusted oil price on lagged measures of freedom.

The oil prices Friedman used are attributed to BP's Statistical Review of World Energy 2005. Friedman seems to have chosen the average yearly spot price per barrel for Nigerian Forcados blend in current U.S. dollars. The figures for economic freedom are more difficult to specify but seem to be those for Legal Structure and Security of Property Rights, taken from the Fraser Institute's Economic Freedom of the World report. For the period 1980 to 2003, five more data pairs are available for the economic freedom measure used by Friedman as well as for the current-dollar oil prices he used. When these are added to the data set, bringing the total number of observations to eight per variable, the correlation is $r=-0.51 ; p=0.201$, far weaker than the result using only three data pairs. When another two data points are added to each variable (for 2004 and 2005; not available to Friedman at the time), the relationship deteriorates even further: $r=-0.25 ; p=0.492$.

It is odd that Friedman confined his measure of economic freedom to just one of the Fraser Institute's 41 freedom measures that the report gathers and compresses into a single index number. It seems reasonable to assume the summary number would give a better indication of the level of economic freedom than any one of its many components. And as already discussed, for an analysis spanning 23 years, oil prices 
Table 2: Nigeria, 1980-2005: correlations for oil price in 2006 U.S. dollars and

Economic Freedom index

$\begin{array}{lcl}\begin{array}{l}\text { Lags } \\ \text { (years) }\end{array} & \begin{array}{c}\text { Pearson's } \\ r\end{array} & \begin{array}{l}p \text { - } \\ \text { value }\end{array} \\ 1 & & \\ 2 & +0.01 & 0.98 \\ 3 & +0.21 & 0.59 \\ 4 & +0.51 & 0.20 \\ & +0.66 & 0.10\end{array}$

ought to be adjusted for inflation. When these variables are graphed in Figure 2 - the two solid lines - and the correlation is computed, then there is insufficient evidence for Friedman's thesis $(r=-0.34 ; p=0.332)$. Moreover, when the economic freedom variable was lagged by one or more years, the correlations turn out to be positive (although not statistically significant; see Table 2).

Friedman's claim for a strong correlation between oil prices and economic freedom in Nigeria is not supported by a wider view of the facts. Friedman cannot claim support for his First Law of Petropolitics in Nigeria.

Russia

Friedman's graph for Russia (not shown here) provides good support for his claim. It clearly shows the measure of a variable called Electoral Process declining as oil prices increase, and it is spread over the years 1998 to 2005 (with 1999 and 2000 having to be reduced to a single point due to difficulties in gaining data). But picking the Freedom House score for Electoral Process as his measure of freedom in Russia is, again, an idiosyncratic choice because it is only one of the seven components used in the Freedom House study Nations in Transit to develop a Democracy Score (the mean of electoral process, civil society, independent media, national democratic governance, local democratic governance, judicial framework and independence, and corruption. $)^{9}$ Friedman's choice of oil price seems to be the spot price for Dubai crude in current dollars. For these variables, the correlation for 1998 to 2005 is excellent ( $r=$ -0.96; $p<0.001)$.

The correlation with the Electoral Process scores holds up very well even when using inflation-adjusted oil prices for the same period. Moreover, when the composite Freedom House score is used, along with inflation-adjusted oil prices, the correlation still looks very good $r=-0.88 ; p=0.004$ ). And when the computations are redone for a longer time period, 1972 to 2006, the correlation is still moderately good ( $r=-0.55 ; p<$ 0.001). Table 3 shows that the strength of the correlation stays at much the same le ve l a n d st a t is tic ally remains highly significant when the Freedom House scores are lagged between one and four years (with the no lag correlation shown for comparison).

However, because two very different regimes existed during this time period, it is reasonable to split it into two parts, the USSR from 1972 to 1990, and Russia from 1991 to 2006. The results are shown in Table 4. The USSR clearly did not conform to Friedman's Law but Russia, over the period 1991 to 2006, showed a reasonably strong negative correlation with high significance for lags of 0 to 3 years. So, it would seem that Russia during this period could be an instance where the First Law of Petropolitics is satisfied.

Iran

In the case of Iran (Figure 3), Friedman graphs oil prices and a measure he calls Freedom to Trade, taken from the Fraser Institute's Economic Freedom of the World report. Taking the best estimates of the data from his chart, it seems this figure represents what the report calls Freedom to Exchange with Foreigners. ${ }^{10}$ His prices for crude oil seem to be, as with Venezuela, the average Dubai spot crude price in current U.S. dollars. ${ }^{11}$ But this example of evidence in support of the First Law of Petropolitics is the most perplexing of all. Even using exactly the same data as provided in Friedman's graph, it clearly contradicts the Law and shows the opposite of what it is meant to show. For most of the given time span, 1995 to 2003, the freedom to trade follows oil price, and the two measures do not begin to diverge until $2002(r=+0.79 ; p=0.11)$. It is difficult to explain this situation. Friedman risked being accused of cherry-picking by choosing a narrow time-frame, selecting an unusual measure for economic freedom, and using current dollars for the price of oil, yet he still arrives at a strong argument against his own thesis. It is possible that he has been diligently even-handed by presenting some counter-evidence. But if that 
were the case he should state it clearly, otherwise the reader can conclude only that it was an example of careless research or editing.

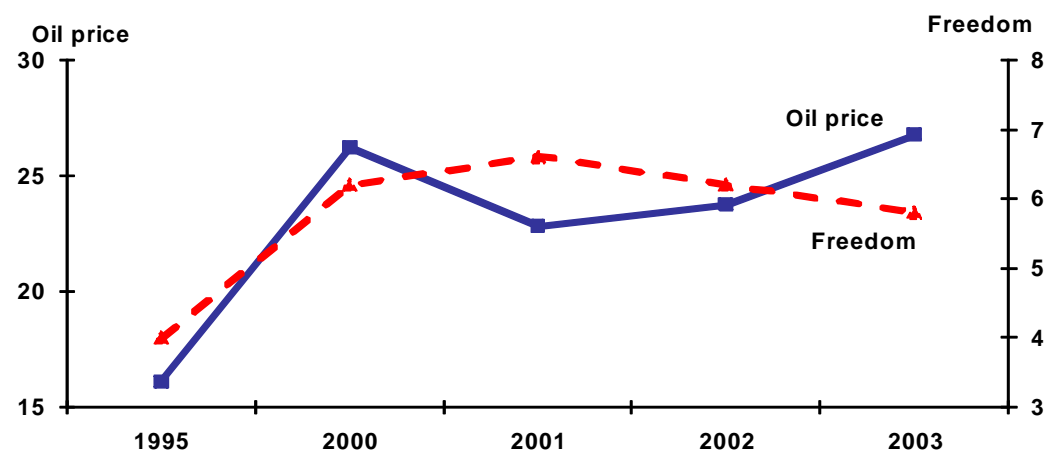

Figure 3: Iran, 1995-2003.

It is strange that Friedman presented figures only for the period 1995 to 2003 which tend to disprove his theory. Extending the time period to include numbers for 1970, 1975, 1980, 1985, 1990, 2004, and 2005 suggests a weak negative, but statistically insignificant, correlation ( $r=-0.2669$; $p=0.4018)$.

Using average crude oil prices in 2006 dollars and the Fraser Institute's more general measure, the Summary Index, ${ }^{12}$ over the same period shows a stronger negative correlation ( $r=-0.4995, p=0.0982)$. However, with only 12 data points, this relationship is heavily influenced by the numbers for 1980 . The economic freedom index fell sharply to reach its lowest point, 4.0, in 1980 and the oil price that year reached its highest value, $\$ 90.46$. This would suggest that here was a case when rising oil prices did cause a decline in freedom. But the correlation is spurious. Both changes were caused by the same event: the 1979 Iranian Revolution.

Thus, the Freedom House score for Iran also seems to negate the First Law of Petropolitics. There is a weak correlation between oil price and the Freedom House score but it is in the wrong direction: the higher the oil price, the higher the level of freedom $(r=+0.37 ; p=0.0294)$. These various ways of looking at the relationship between oil price and freedom in Iran show there is no support for Friedman's Law.

\section{Petrolist states in general}

Thus far the analysis deals with only four of Friedman's “petrolist” states. Nine other countries are included in Friedman's list of petrolist states, albeit without data. They are: Azerbaijan, Angola, Chad, Egypt, Equatorial Guinea, Kazakhstan, Saudi Arabia, Sudan, and Uzbekistan. As a final exercise, then, data for all 13 countries on the list were collected. The freedom measures were the inverted Freedom House scores and
Table 5: 13 petrolist countries, and how the price of oil correlates with three measures of freedom, 1972-2006

\begin{tabular}{|c|c|c|c|c|c|c|c|c|c|c|c|c|}
\hline & $\mathrm{FH}$ & (in) & erte & & $E F$ & & & & $P S$ & & & \\
\hline Lag (years) & 0 & 1 & 2 & 4 & 0 & 1 & 2 & 4 & 0 & 1 & 2 & 4 \\
\hline Angola & $\mathrm{Y}$ & & & & & & & & Y & $\mathrm{Y}$ & $\mathrm{Y}$ & $\mathrm{Y}$ \\
\hline Azerbaijan & & & & & & & & & & & & $\mathrm{Y}$ \\
\hline Chad & $\mathrm{Y}$ & & & & $\mathrm{Y}$ & & & & $\mathrm{N}$ & $\mathrm{N}$ & & \\
\hline Egypt & $\mathrm{N}$ & $\mathrm{N}$ & & & $\mathrm{Y}$ & & & & $\mathrm{N}$ & & & \\
\hline Equat. Guinea & & & & $\mathrm{N}$ & & & & & $\mathrm{Y}$ & $\mathrm{Y}$ & $\mathrm{Y}$ & \\
\hline Iran & $\mathrm{N}$ & $\mathrm{N}$ & $\mathrm{N}$ & & & & & & & & & \\
\hline Kazakhstan & & & & & & & & & $\mathrm{Y}$ & $\mathrm{Y}$ & $\mathrm{Y}$ & $\mathrm{Y}$ \\
\hline Nigeria & $\mathrm{N}$ & $\mathrm{N}$ & $\mathrm{N}$ & & & & & & $\mathrm{N}$ & $\mathrm{N}$ & $\mathrm{N}$ & \\
\hline USSR-Russia & $\mathrm{Y}$ & $\mathrm{Y}$ & $\mathrm{Y}$ & $\mathrm{Y}$ & $\mathrm{N}$ & $\mathrm{N}$ & $\mathrm{N}$ & $\mathrm{N}$ & $\mathrm{Y}$ & $\mathrm{Y}$ & $\mathrm{Y}$ & $\mathrm{Y}$ \\
\hline Saudi Arabia N & $\mathrm{N}$ & $\mathrm{N}$ & $\mathrm{N}$ & & & & & & & & & \\
\hline Sudan & $\mathrm{N}$ & $\mathrm{N}$ & $\mathrm{N}$ & & & & & & & & & \\
\hline Uzbekistan & & & & & & & & & & & & \\
\hline Venezuela & $\mathrm{N}$ & $\mathrm{N}$ & $\mathrm{N}$ & & $\mathrm{N}$ & & & & & & & \\
\hline
\end{tabular}

Note: $\mathrm{FH}=$ Freedom House; EFI = Economic Freedom Index; PS = Polity score; $\mathrm{Y}=$ instances which lend some support to Friedman's claim $(r<0 ; p<$ $0.1) ; \mathrm{N}=$ instances which tend to contradict Friedman's claim $(r>0 ; p<$ 0.1 ); empty cells = instances where the data cannot be used to support or contradict the claim or data is not available.

the Fraser Institute's summary index of economic freedom, as discussed previously. In addition, a measure derived from the Polity IV data set was used as well. ${ }^{13}$

A summary of the results is given in Table 5 (and full details are available from the author). With 13 petrolist states, three measures of freedom, and lags of $0,1,2$, and 4 years, there are 156 opportunities for Friedman's claim to be substantiated. However, only 24 instances support his claim, that is, when the statistical significance is better than 90 percent and the correlation is negative. In 66 cases, the results neither support nor contradict the claim, and in 36 cases the data is not available. In 30 instances, the claim is contradicted: that is, the statistical significance is better than 90 percent but the correlation is positive. Only one country, Angola, showed support for the claim across more than one measure of freedom without having any contradicting cases. Russia showed strong support for the claim using all lag periods of Freedom House and Polity scores but was contradicted by all lag periods for economic freedom scores. 


\section{Conclusion}

As has been shown, there is almost no support for Friedman's First Law of Petropolitics in the four countries for which he provided data. The claims he draws from his data fail to hold when the time period is widened or if oil prices are presented in inflation-adjusted terms. A lag in the effect of changes in oil price is highly likely yet when this is introduced into the analysis, this tends to contradict the Law. In the case of Iran, Friedman's own figures contradict his claim.

It should not be surprising that a single factor such as price cannot explain a complex process like political reform. Many other influences need to be considered. As in the case of Iran, an apparent correlation can be shown to be spurious because the price rise and the decline in freedom were both due to another factor, the Iranian Revolution. It should be pointed out that there could still be a causal link between oil price and political reform but it is being disguised by other factors. Using multiple regression analyses that include factors such as GDP growth, GDP per capita, military expenditure, and levels of taxation, no sign of clear relationships emerge. Also, for a proper analysis of the effects of oil on political reform other measures of oil wealth need to be considered such as the extent of reserves, production levels, production costs, revenues, profits, and ownership. But at this point it can be confidently stated that price alone is not been able to explain the level of democracy in the countries studied here.

\section{Notes}

Steve Townsend is a Ph.D. candidate in the Department of Government and International Relations at the University of Sydney, Australia. He may be reached at st@recognition.com.au.

1. Horiuchi and Waglé (2008); Ramsay (2006); John (2007).

2. Friedman (2006).

3. Anonymous (2007); Paul (2006); The Economist (2007).

4. Cole (2007); Mignone (2007); Stevens and Dietschea (2008); Mingst and Snyder (2007).

\section{Friedman (2006).}

6. Actually, it is difficult even to determine just what measure Friedman used for nominal oil prices. He offers the data not as numbers but only as positions on his graph. He attributes the data to "BP Statistical Review of World Energy 2005 and
IEA” (Friedman, 2006). The International Energy Agency (IEA) reports do provide information on current energy balances and conversion factors for all types of energy production and consumption but they do not provide historical data on crude oil prices that are as complete as the BP data. BP's Review provides several series of oil prices. After comparing the graphed data with the sources cited, it appears that Friedman used the series for yearly average spot price for crude oil sold in Dubai, and that the units are U.S. dollars per barrel in current prices.

7. In this article, the Freedom House scores are presented in inverse order. This is because the Freedom House scores range from 1 (democratic) to 7 (authoritarian). That is, the more freedom, the lower the score, exactly opposite to the way other measurements of freedom are handled. The tag "(inverted)” will appear with al Freedom House scores used here to indicate that this transformation has been made. That Freedom House's original scores run in the opposite direction to other measures of freedom makes it particularly confusing when looking at negative correlations. So, throughout this article a Freedom House score of $x$ will be presented as its additive inverse with respect to eight. That is, it will be converted to $8-x$. Thus we will be dealing with scores ranging from 7 (democratic) to 1 (authoritarian). Note also that during the period 1982 to 1989, Freedom House made changes in the timing of its collection years. It used several different collection periods before settling on calendar years in 1990. I have overcome this inconsistency by regarding all years as calendar years and interpolating values for 1989 as the mean of the values for 1988 and 1990

\section{Freedom House (2007); BP (2008).}

9. Freedom House (2006). As with other Freedom House scores, the composite score ranges from 1 (democratic) to 7 (authoritarian), and in the reported calculations the inverse of the score has been used.

10. Gwartney, Lawson, and Gartzke (2005).

\section{BP (2007).}

12. The figures for Freedom to Exchange with Foreigners for 1970 and 1975 come from the Fraser Institute's Economic Freedom of the World Report 2003 while the figures for other years are from the 2007 report. BP reports Dubai spot crude prices only as far back as 1972 when the price was $\$ 1.90$ in current dollars. I have put the 1970 price at $\$ 1.80$, which is actually the world average spot crude oil price in current dollars. This would seem to be a reasonable approximation. 
(C) www.epsjournal.org.uk - Vol. 4, No. 1 (2009)

13. The Polity database uses a variable called POLITY which results when the AUTOC score is subtracted from the DEMOC score. It gives values ranging from -10 to +10 . The AUTOC and DEMOC variables contain "standardized authority scores," $-66,-77$, and -88 , to indicate periods of transition, war, etc. These scores are carried over into the POLITY variable, so that the Polity IV project provides another variable, POLITY2, which modifies these scores to make the data more usable in time series analyses. Following Ross's example, my Polity score variable is POLITY2 adjusted to give positive values ranging from 0 to 10 . That is, 10 is added to the POLITY2 score to make all the numbers positive, then the result is halved to bring it into the range 0 to 10 .

\section{References}

Anonymous. 2007. "First Law of Petropolitics." Private Sector Development Blog, Vol. 6. http://psdblog.worldbank.org/psdblog/2006/04/first_law_of_pe.html [accessed 13 March 2008].

BP. 2008. Statistical Review of World Energy 2007. http://www.bp.com/productlanding.do?categoryId=6848\&contentId=7033471 [accessed 30 October 2008].

Cole, N.S. 2007. "Hugo Chavez and President Bush’s Credibility Gap: The Struggle Against U.S. Democracy Promotion.” International Political Science Review, Vol. 28, No. 4, pp. 493-507.

[The] Economist. 2007a. "All puffed up and stalling on reform.” The Economist, Vol. 382, No. 8518, p. 53.

Freedom House. 2006. Nations in Transit. Lanham, MD: Rowman \& Littlefield and Freedom House.

Freedom House. 2007. Freedom in the World: Country Ratings, 1972-2007. New York: Freedom House.

Friedman, T.L. 2006. “The First Law of Petropolitics.” Foreign Policy (May/June), pp. 28-36.

Gwartney, J., R. Lawson, and E. Gartzke. 2005. Economic Freedom of the World: 2005. Annual Report. Vancouver, B.C.: Fraser Institute.

Gwartney, J., et al. 2007. Economic Freedom of the World: 2007. Annual Report. Vancouver, B.C.: Fraser Institute.

Horiuchi, Y. and S. Waglé. 2008. "Is Oil Bad for Democracy? Replication and New Analysis.” Crawford School of Economics and Government, Australian National University, Canberra, Australia.

John, J.D. 2007. “Oil Abundance and Violent Political Conflict: A Critical Assessment.” Journal of Development Studies, Vol. 43, No. 6, p. 26, pp. 961-986.

Marshall, M.G., K. Jaggers, and T.R. Gurr. 206. Polity IVd Project Dataset. Center for International Development and Conflict Management, University of Maryland.

Mignone, B. 2007. "The National Security Dividend of Global Carbon Mitigation.”
Energy Policy, Vol. 35, No. 11, p. 5403-5409.

Mingst, K.A. and J.L. Snyder, eds. 2007. Essential Readings in World Politics. New York: W.W. Norton: New York.

Paul. 2006. "Mr. Metaphor and the First Law of Petropolitics.” Truck and Barter Blog. http://truckandbarter.com/mt/archives/2006/05/mr_metaphor_and.html [accessed 13 March 2008].

Ramsay, K.W. 2006. Natural Disasters: Price of Oil and Democracy. Princeton, NJ: Princeton University Press.

Stevens, P. and E. Dietschea. 2008. "Resource Curse: An Analysis of Causes, Experiences, and Possible Ways Forward.” Energy Policy, Vol. 36, No. 1, pp. 56-65. 